\title{
The Image of Ukraine Through Regions: The Actual Experience with Free Association Method
}

\author{
Alla Petrenko-Lysak [0000-0002-1316-5002], Olga Bezrukova * [0000-0003-4305-6218] \\ Taras Shevchenko National University of Kyiv, Ukraine \\ *o.bezrukova@knu.ua
}

\begin{abstract}
The aim of the article is to demonstrate capacities of a qualitative analysis of data collected by the free association method. The empirical base of the research included results of a research by students, aimed at comparing ideas about the Ukraine by students. To establish a group typology of the attitudes to the Ukrainian regions that authors used the free association method. The data were analysed by two approaches - by division of associations into concept categories and by division into positive and negative associations. The results can become the basis for reflections about young generation of Ukrainian citizens and the decision-making of the faculty leadership towards of the formation of students citizenship.
\end{abstract}

Keywords: sociology of space, methods of sociological research, territory image, Free Association method, Region.

\section{INTRODUCTION}

Among the competences, defined by Higher Education Standard for training of sociologist, obtaining bachelor`s degree, are the following: «CC $11^{1}$. The ability to exercise their civic rights and duties, to realize the civil (free democratic) society values and the need for its sustainable development, the rule of law, Ukrainian citizen rights and freedoms» [1]. Therefore, in order to form the mentioned-above competences effectively, it is important to understand what image of their own country second-year students have. During the five-year teaching the «Sociology of Space» course, we have implemented the Free Association method not only as a subject for professional training, but as a research tool as well. This method seems to be one of the best ways to capture the visual context of people's ideas. This technique is aimed at identifying the associations, a person has developed during the previous experience. The association is a double process of the correlation of the object (stimulus) with the first content (response) when we are characterizing the mechanism of associations. On the one hand, the individual reproduces personal experience while associating, on the other - this is a repetitive typical, that is speech and social experience [2].

The associative method is widely used in psychology, linguistics, philosophy, anthropology, social geography and in interdisciplinary researches. Psychologists identify emotions, feelings, sensations by means of associations. Linguists study the associations in language. Psycholinguistics deals with a narrower range of associative processes, mainly paying attention to the verbal reflection of the language and thinking interaction $[3,4,5]$. The association method is used for practical purposes in psychiatry, psychoanalysis, social work, marketing. For instance, marketers use it in development of brand positioning strategies. The method is also used by sociologists. The approach to the associations study in sociology differs from the approaches of other sciences. For example, while the temporary, non-permanent nature of associative connections, change of some associations to others are important for psychological research, important stable characteristics of associations, their social bases, interrelation with various social phenomena and social processes are important for sociology. In the broadest context, there are the following options for the Free Association method implementation in sociology: the Free Association method, the method of directed associations, the method of incomplete sentences. The application of the associative approach in sociology has several advantages over the use of other methods.

First of all, its arrangement and implementation are quite simple and low-cost. During this kind of sociological research, the respondent is usually asked to

${ }^{1}$ common competencies 
name or write some associations, choosing them from a set of stimuli. These associations are caused by a particular stimulus. The researches use a word, phrase, picture, photograph or object as an incentive. The things are selected in accordance with the objectives of the study. The free associations method is even simpler, because it does not specify the theme or scope of answers.

Secondly, according to the experience of using the associative method $[6,7]$ in empirical $[8,9]$ sociological research, the questions, identifying the association, arouse the respondents' genuine interest and «live reaction». Thus, researchers note that the rejection percentage is low, just on the contrary many people give even several answers. In addition, the absence of answers are no less important in this case, because they indicate the lack of associations in the consciousness of the social object.

Thirdly, the association method, being mainly auxiliary, brings a qualitative component to quantitative research and server as a connection between qualitative and quantitative methods. The total number of associations and that of certain types can be calculated. The data of such an experimental study, indeed, are processed to identify connection of most common associations with stimulus, given by researches. Consequently, the researcher receives an «associative field», built of typical associations, which are the most common and research are interested for. The other answers are unique associations. They seem to be purely individual, however they also reflect the social characteristics of the studied set of objects. Thus, a significant indicator is said to be the ratio of typical and atypical associations. At the same time, the most interesting results are often given not by quantitative calculation, but by the general state of the associative field. The considerable quantity of typical associations indicates the predominance of stereotypes of certain phenomena perception and directs research to identify the social factors determining the «pattern» of responses.

Fourthly, the association method provides a significant amount of information. It gives an opportunity to establish the nature of semantic or emotional connotations additionally to the content component. Associations can have a positive, negative or neutral emotional and semantic charge, and this predetermines the association and stimulus interpretation.

Fifthly, the method of associations enables the informant to fall outside the scope of a particular situation or social role, usually set by surveys with mostly closed questions. The researcher has the opportunity to obtain more objective results without predetermined formulations.

And, sixthly, the associative method is convenient for the studies of phenomena and processes without detailed and reliable data because these studies is just beginning.
The associative method gives an ability to establish the interrelation of phenomena, processes, factors, the content of which we haven't had yet a clear idea.

During research, conducted by means of the Free Association method, we took notes of the ideas of sociology department students about Ukrainian regions. As for the theory, we used the definition of the image by Dmitry Zamyatin, who defines it as the most distant and indirect representation of reality $[10,11]$. The word «image» means not only a certain form of reflection of objects in human consciousness, but also its features, appearance, visual representation, location, parameters, outlines, important characteristics. Thus, the image of the territory is a set of ideas about space within its specific features and patterns of development [12-14]. The image formation is influenced by such factors as: internal - the nature of the territory and its history familiarization, social structure, economic activities, settlement, and external - geographical location, role in the history of the country, the history of perception of the territory, media discourse. The components of these groups can have both internal and external origin. The image itself consists of different parts with both positive and negative connotations. The image components form the status of the region, that is the region place in the structure and hierarchy of other regions of the country: the degree of development, role in economic, political, cultural life of the country. The region status is determined by the potential and resources of particular city, which is a key area for change and the region associated with. As well as the external relations, the region may have both internal and external ones if it borders another country.

\section{RESEARCH METHODOLOGY}

Sociology department students master the Associations Method within the course «Sociology of Space». Along with the formation of professional skills, students directly practice the method, being an informant. They do this in order to understand better informant's condition during the study. Being researchers we received an empirical data array. It shows the image of the Ukrainian regions in the imagination of sociology department students in the period 2015, 2017-2021. The test subjects were also students in geography for two years (2020-2021) [15-17]. They are a kind of «control group» of naturalists as opposed to the humanistic groups of sociologists. Thus, the purpose of our case is to form students' skills in working with the Free Association method and collecting information (data array) about the associative reflection of the Ukrainian regions, forming together the image of the country as a whole. Our study was not aimed at identifying the linguistic or psychological aspects of associations. We sought to identify the «social component» of associations, to understand through which associations; the social ideas of students about the regions of the country are reflected $[18,19]$. 
We addressed the students-informants as follows: "Here you have the names of the regions of Ukraine. Write in each gap your first associations (adjectives, events, names, things, objects, images, colors - anything). You shouldn't strain the memory; only associations, easily and quickly formed. If associations do not arise, you do not write anything».

\section{RESULTS OF THE RESEARCH}

Image connotations in the answers of informants.

Positive: the best, rich city, cleanliness (Vinnytsia Region); advanced, beautiful, bright city (Dnipropetrovs`k Region); very wonderful city, polite people, warmth, beauty, nice people (Lviv Region); warmth (Kherson Region); coziness (Poltava region); developed city, wonderful people, attractions (Rivne region); cleanliness (Chernihiv Region); wonderful people (Ternopil Region); beautiful architecture, wonderful parks and squares, charming (Kharkiv Region); good roads (Cherkasy Region); special atmosphere (Odesa Region); well-designed houses (Sumy Region); wonderful parks (Ivano-Frankivs`k Region).

Negative: gloomy city, low income, aggression, destruction (Donets`k Region); empty city, stale air (Zaporizhzhya Region); poverty, ignorance, gray masses, «terrible roads, unfriendly people, lack of comfort and civilization» (Kirovograd Region); gray mass, conflicts, decline (Luhans`k Region); grayness, selfishness (Kharkiv Region); emptiness (Ternopil Region); sadness (Crimea); very bad roads, wasteland (Mykolaiv Region), impassable roads (Khmelnitsky Region); banditry (Dnipropetrovs`k Region); cold autumn, conservatism (Volyn Region).

It worthwhile mentioning that this division of associations into positive and negative is conditional. We were guided by generalized ideas and common sense, establishing the nature of the connotation $[19,20]$.

The main types of associations are grouped by the following features - semantic categories:

- industrial (Luhans`k Region - industry; Dnipropetrovs`k, Mykolaiv Regions - factories; Vinnytsya Region - Roshen; Donets`k Region - coal, mines; Zhytomyr Region - socks; Zaporizhzhya Region - Hydroelectric power plant; Mykolaiv Region - port; Rivne Region - Nuclear power plant; Cherkasy Region reservoir);

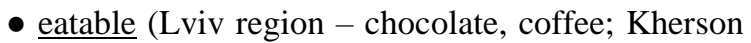
region - watermelon, tomatoes, sunflowers, fruits; Vinnytsia region - chocolate, candy; Poltava region -

\footnotetext{
${ }^{2}$ traditional variety of thick, soft noodles or dumplings

${ }^{3}$ semi-autonomous polity and proto-state[2] of Cossacks in the 16th to 18 th centuries

${ }^{4}$ range of mixed sociolects of Ukrainian and Russian languages used in certain regions of Ukraine
}

halushky ${ }^{2}$ (dumplings); Chernihiv region - beer; Dnipropetrovs`k region - beets);

- cultural and historical (Zaporizhzhya Region Cossacks, Sich ${ }^{3}$, Khortytsia island; Lviv Region culture; Ivano-Frankivs`k, Ternopil, Kharkiv Regions language, Poltava region - surzhyk ${ }^{4}$; lyrics: Ternopil Region - «nice city», Zhytomyr Region - «not the city, not the village» ${ }^{5}$; Chernihiv Region - history);

- tourist (Vinnytsya Region - fountain(s); Chernivtsi Region - university; Volyn Region - castle; Lviv Region - architecture; Rivne Region - Love Tunnel; Chernihiv Region - churches);

- recreational (Zakarpattya Region - air; Odessa Region - resort, rest; Crimea - rest, Artek $\left.{ }^{6}\right)$;

- landscape (natural: Odessa, Mykolaiv Regions, Crimea - sea; Zakarpattya, Ivano-Frankivs`k Regions, Crimea - mountains, Carpathians; Dnipropetrovs`k Region - Dnipo river; Volyn Region - lakes, forest; Rivne Region - field, swamps, forest; and architectural: Kharkiv Region - city park; Dnipropetrovs`k Region Embankment; Kirovograd, Khmel`nitsky Regions terrible and impassable roads; Cherkasy Region - dike, roads; Khme`lnits`ky Region - bazaar $^{7}$, market);

- political (Luhans`k, Donets`k Regions - war, occupation, Donets`k People`s Republic (DNR), Luhans`k People`s Republic (LNR); Crimea annexation; Kyiv Region - capital, center);

- geographical (Kyiv, Kirovohrad Regions - center; Volyn Region - west; Rivne Region - amber; Sumy Region - Konotop city, Hlukhiv city, border, north; Khmel`nyts`ky Region - Kam`yanets`-Podilsky city; Cherkasy Region - Kaniv city);

- educational (Kharkiv Region - university, students);

- personal (home; family; names of people, friends; celebrities: Ternopil Region - Prytula; Kharkiv Region Kernes; Vinnytsya Region - Poroshenko, Groysman; Donets`k Region - Akhmetov; Dnipropetrovs`k Region - Kolomoisky, Tymoshenko; Ivano-Frankivs`k Region Ivan Franko; Poltava Region - Gogol, Poltavka; Khmelnytsky Region - Bogdan; Cherkasy region Shevchenko; ethnic groups: Ivano-Frankivs`k Region Hutsuls, Odesa Region - Jews).

Some regions were associated with colors: light green (Zhytomyr Region), orange (Luhans`k Region), white (Sumy Region), blue (Cherkasy Region), gray (Khmelnytsk Region), green (Mykolayiv Region).

\footnotetext{
${ }^{5}$ words from the famous song about Zhytomyr

${ }^{6}$ is an international children camp (a former Young Pioneer camp) on the Black Sea in the town of Gurzuf located on the Crimean Peninsula ${ }^{7}$ a popular and well-known marketplace in Khmelnitsky
} 
Kyiv Region is the only one that has such associations as: crowd, rhythm, chaos.

Three regions were noted by mentioning positive characteristics of people, namely: polite people, nice people (Lviv Region); wonderful people (Rivne, Ternopil Regions).

The image of the region represented by the title city (regional center) is recorded in Vinnytsya, Odesa, Kharkiv, Kyiv and Lviv Regions.

The regions that received the largest number of «gaps»: Rivne, Cherkasy, Khmelnyts`ky, Sumy Regions. This is due to not only their image in mass media, but also to the fact that the number of students of the Sociology Department, living in these regions, are small. Consequently, we have a few individualized images. However, this fact one way or another indicates that these areas are scarcely mentioned in public discourse.

\section{DISCUSSION OF RESULTS}

Consequently students as informants were asked to write words, thoughts, ideas, images that arise with the name of the region of Ukraine mentioned. As a result for the period 2015-2021 we have a total of 81 responses from young people, at the age of 19-20, students of the Sociology Department, who chose a selective course in the field of «Sociology of Urbanization and Globalization».

The image of Ukraine in the set of associations connected with mentioning the name of Regions, indicates that the images are quite clearly formed by the mass media, stereotypes and common communicative context. When we together with the students analyzed answers further, they said half of the words mentionedabove, they knew not due to their own experience of visiting the area, but to the news or widespread information sources such as travel guides, school textbooks, stories of acquaintances, rumors. Personal markers of associations were the indication of the names of acquaintances, relatives, friends, as well as a word «home», or the indication of individual facts, being clearly understood as a unique personal experience of the informant.

Actually, there is a small number of adjectives in the list of associations. Mostly nouns. The image of Ukraine is diverse, expressed by geographical and landscape, industrial and cultural and recreational characteristics. Ukraine appears as a natural territory (forests, mountains, sea) and an industrial country (factories, hydroelectric power plants, nuclear power plants) in the emotional context, which makes it possible to speak on the negative or positive background of ideas. The social context of the image is the territory, engaged in hostilities, and regions with recreational and tourist facilities.

The most stereotyped images (the word-association that occurs the most times) are: Vinnytsya Region- fountains (фонтани) and Roshen factory (Рошен) (Figure 1); Dnipropetrovs`k Region - factories (заводи) and Dnipro river (Дніпро) (Figure 2); Odesa Region the sea (море) and the Jews (свреї) (Figure 3); Mykolaiv Region - sea (море) and port (порт) (Figure 4); Donets`k and Luhans`k Regions - coal (вугілля), mines (шахти) and war (війна), anti-terrorist operation (ATO) and the airport (аеропорт - as a symbol of war), DNR (ДНР) and LNR (ЛНР) (Figure 5; Figure 6); Kherson Region watermelons (кавуни) and tomatoes (помідори) (Figure 7); Zaporizhzhya Region - Cossacks (козаки) (Figure 8).

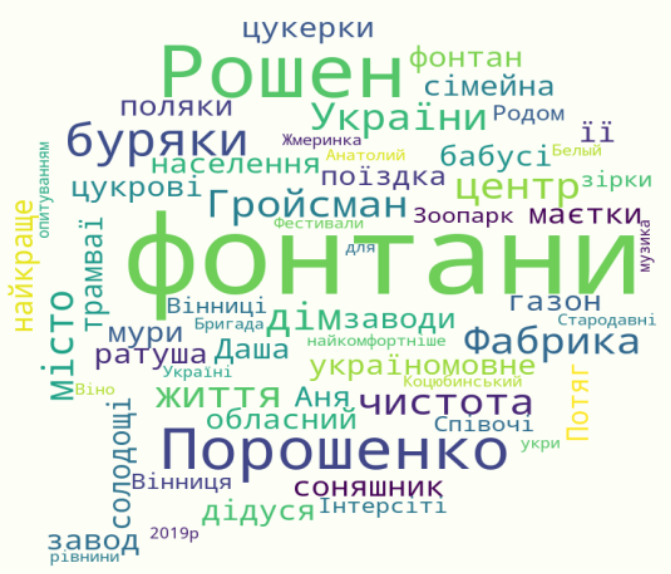

Figure 1 Vinnytsya Region

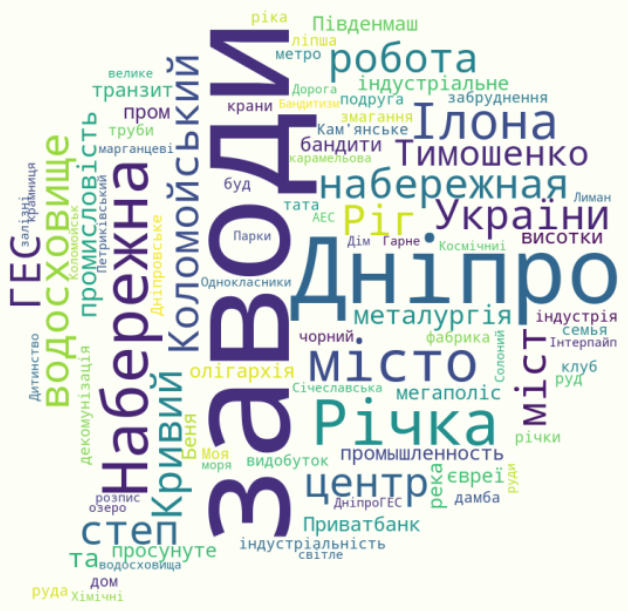

Figure 2 Dnipropetrovs`k Region 
Beach

Приво $3^{\text {хупьтурная }}$

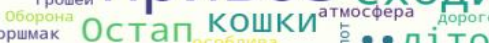

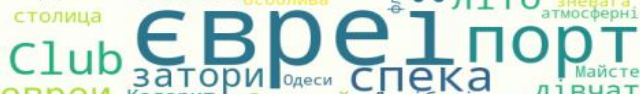
евреи каторинеи Спека дівчата ринок Ibiza

Чорне

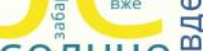

хасиди ВорИКИ краше солНЦе..

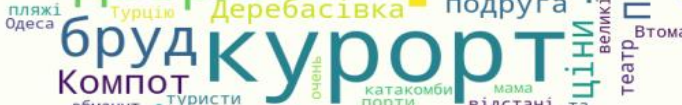

компот

ВІДПОЧИНОК

ВИНО ГУМОрпляж

BИCOKI

Figure 3 Odesa Region

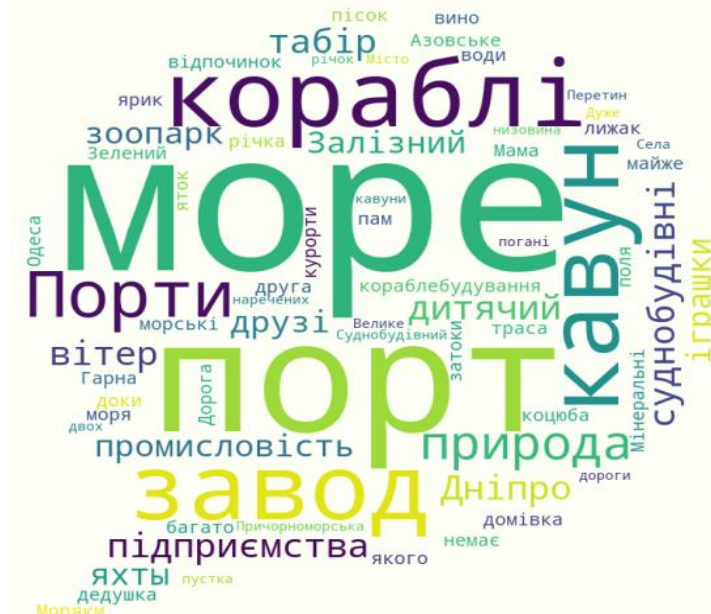

Figure 4 Mykolaiv Region

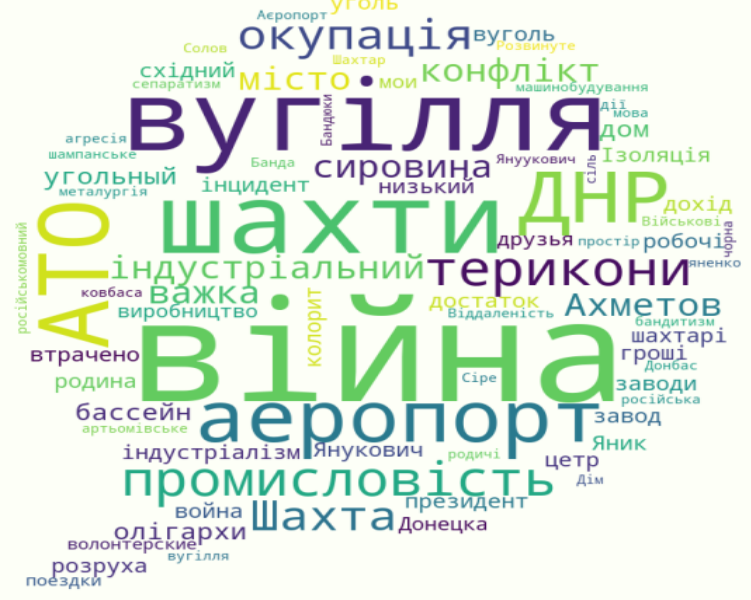

Figure 5 Donetsk

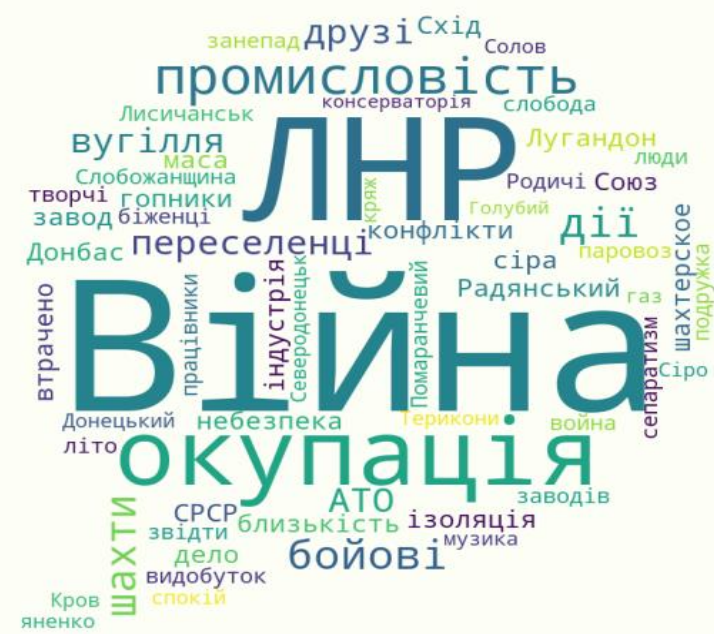

Figure 6 Luhans`k Regions

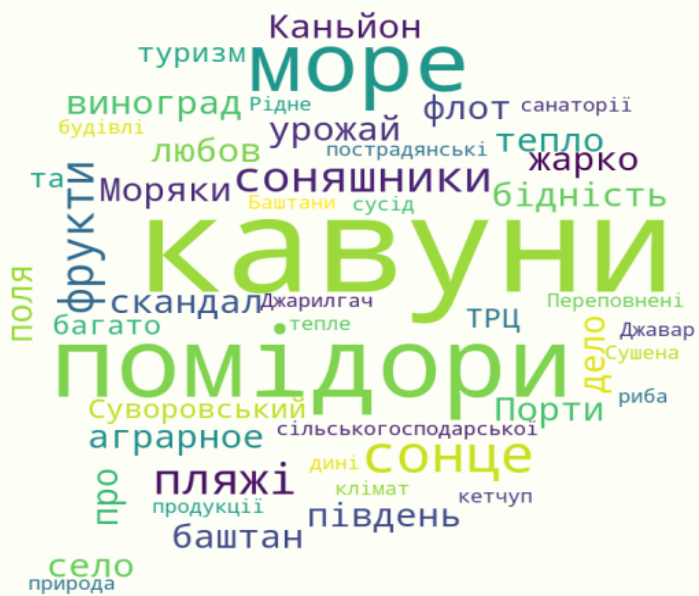

Figure 7 Kherson Region

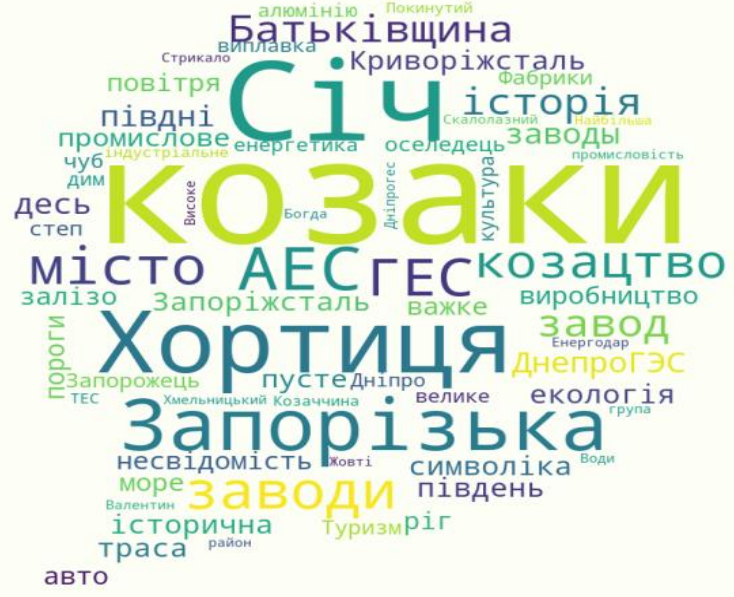

Figure 8 Zaporizhzhya Region 


\section{CONCLUSIONS}

The method of associations has great cognitive potential and multivariate analysis. The associative approach is rather an additional, clarifying method, or conversely a method of formulating tenable hypotheses in traditional sociology. One of its positive characteristics is that it does not impose informants to answers in a particular way. It gives people an opportunity to feel free to express themselves, rescinds them from their social statuses and roles, accompanying informant-respondents in most sociological methods.

The semantic associations obtained by sociologists are manifestations of the relations between a certain object, phenomenon or process of social reality (we have the Regions of Ukraine) and the reaction-representation (image) that arises at a certain time. These associations reflect both a person`s life experience and the social

\section{REFERENCES}

[1] Standart vishchoï osviti Ukraïni, Special'nist' - 054 Cociologiya, available at: https://mon.gov.ua/ storage/app/media/vishcha-osvita/zatverdzeni\% 20standarty/2021/07/28/054-Sotsiolohiyabakalavr.28.07.doc

[2] Chen, Lv. and Li, Xiaoyan (2021), "Reconstruction: Key to Social Responsibility Risk Assessment for Tourism Investment Projects", Journal of Risk Analysis and Crisis Response, vol. 11 (1), pp. 1-9. DOI:10.2991/jracr.k.210111.002

[3] Goroshko, E.I. (2001), Integrativnaya model' svobodnogo associativnogo eksperimenta, RaKaravella, M.-Har'kov, Russia.

[4] Denisevich, O. Vil'nij asociativnij eksperiment yak zasib doslidzhennya social'nogo portretu, available at: http://dspace.nbuv.gov.ua/bitstream /handle/123456789/37537/42-Denysevych.pdf

[5] Ivanova, N.A. (2013), "Primenenie metoda svobodnyh associacij $\mathrm{V}$ empiricheskih sociologicheskih issledovaniyah", Vestnik SanktPeterburgskogo universiteta, Sociologiya, ser. 12, vyp. 3, ss. 116-122, available at: https://cyberleninka.ru/article/n/primeneniemetoda-svobodnyh-assotsiatsiy-v-empiricheskihsotsiologicheskih-issledovaniyah/viewer

[6] Pautova, L.A. (2007), “Associativnyj eksperiment: opyt sociologicheskogo primeneniya", Sociologiya: metodologiya, metody, matematicheskoe modelirovanie, № 24, ss. 149168, available at: https://www.jour.fnisc.ru/ index.php/soc4m/article/view/4117/3858

[7] Puzanova, ZH.V. and Larina, T.I. (2017), "Ispol'zovanie metodiki associacij dlya izucheniya otnosheniya k stranam", Izvestiya vysshih uchebnyh zavedenij, Povolzhskij region, Obshchestvennye experience of the communities and groups, the individual belongs to. Respondents' associations may often have nothing to do with reality and be represented through stereotypes, rumors, media discourse and many other communicative and socializing factors. As result, the reflected reality is distorted, transformed. However, in the end, no matter how relevant the associations are, the method makes it possible to record information about a social phenomenon or object, about the opinion and evaluative judgments, memory and attitudes of informants. In our analysis, we used two ways of analysis of the associations array to obtain a typology: 1) the division into positive and negative associations, allowing us to clarify specific facts and definitions in relation to the areas; and 2) the division into semantic categories, with the help of which we found the clearest ideas about the regions of the country separately and the image of Ukraine as a whole.

nauki, Sociologiya, № 1 (41), ss. 98-110, available at: https://izvuz_on_eng.pnz gu.ru/files/izvuz_on_eng.pnzgu.ru/on_1_2017.pdf

[8] Arnold Adimabua Ojugo and Obinna Nwankwo (2021), "Tree-classification Algorithm to Ease User Detection of Predatory Hijacked Journals: Empirical Analysis of Journal Metrics Rankings", International Journal of Engineering and Manufacturing (IJEM), vol. 11, no. 4, pp. 1-9. DOI: $10.5815 /$ ijem.2021.04.01

[9] Prabhjot Kaur, Yashita Pruthi, Vidushi Bhatia, Janmjay Singh (2019), "Empirical Analysis of Cervical and Breast Cancer Prediction Systems using Classification", International Journal of Education and Management Engineering (IJEME), vol. 9, no. 3, pp.1-15. DOI: $10.5815 /$ ijeme.2019.03.01

[10] Zamyatin, D.N. (2006), Kul'tura i prostranstvo: Modelirovanie geograficheskih obrazov, Znak, Moskva, Russia.

[11] Zamyatin, D.N. (2003), Gumanitarnaya geografiya: Prostranstvo obrazov $i$ yazyk geograficheskih obrazov, Aletejya, SPb., Russia.

[12] Reutov, V.E. Mitina, E.A. and Kalkova, N.N. (2020), "Formation and Promotion of the Territory Brand of the Neuromarketing Tools", International Scientific Conference "Far East Con" (ISCFEC 2020), Series "Advances in Economics, Business and Management Research”, vol. 128, pp.13751383.

[13] Falko, L.Y. Metlyaeva, T.V. Klochko, I.L. and Slesarchyk, I.A. (2020), "The Territory Image Assessment with Reference to Its", International Scientific Conference "Far East Con" (ISCFEC 2020), Series "Tourism Attractiveness Advances in 
Economics, Business and Management Research", vol. 128, pp.1019-1028.

[14] Bystrova, T. and Kochetkov, D. (2017), "Branding as an identification of the territory potential: insufficiency of constructivist approach", Second International Conference on Economic and Business Management (FEBM 2017), Series "Advances in Economics, Business and Management Research”, vol. 33, pp. 907-916.

[15] Butova, T.G. Bukharova, E.B. Ulina, S.L. Yakovleva, E.Y. and Morgun, V.N. (2020), "Territory Branding Modelling: Problems and Solutions", International Scientific Conference "Far East Con" (ISCFEC 2020), Series "Advances in Economics, Business and Management Research”, vol. 128, pp. 2608-2611.

[16] Ushakova, E.O. and Tsoy, M.Y. (2020), "Methods for Assessing the Tourist and Recreational Potential of the Territory", International Scientific Conference "Far East Con" (ISCFEC 2020), Series "Advances in Economics, Business and Management Research”, vol. 128, pp.2636-2640.

[17] Santos-Reyes, J. and Awareness, Multi-hazard (2020), "Risk Perception and Fear to Earthquakes: The Case of High-school Students in Mexico City", Journal of Risk Analysis and Crisis Response, vol. 10 (3), october, pp. 91-96. DOI: 10.2991/jracr.k.200923.001
[18] Vasilyeva, M.R. (2019), "Visual Research and the Problem of the Visual Object", Humanities and Social Sciences: Novations, Problems, Prospects (HSSNPP 2019), Series "Advances in Social Science, Education and Humanities Research", vol. 333, pp. 656-660.

[19] Popova, A. (2019), "Understanding of Visual Sociology as an Independent Discipline", 4th International Conference on Contemporary Education, Social Sciences and Humanities (ICCESSH 2019), Series "Advances in Social Science, Education and Humanities Research", vol. 329, pp. 2124-2127.

[20] Jing, Yang (2017), "How to Carry Out Benign Social Construction and Management through Sociological Perspective", 7th International Conference on Management, Education and Information (MEICI 2017), Series "Advances in Intelligent Systems Research”, vol. 156, pp.751755.

[21] Mayakova, A. "Factors of emerging socio-cultural risks in the era of digitization and economization", 1st International Scientific Practical Conference "The Individual and Society in the Modern Geopolitical Environment" (ISMGE 2019), Series "Advances in Social Science, Education and Humanities Research”, vol. 331, pp.458-461. 